\title{
Study About Targeted Leverage Determinant Behavior and Speed of Adjustment in Secondary and Tertiary Sectors in Indonesia Stock Exchange
}

\author{
Purwanto Widodo* \\ Fakultas Ekonomi dan Bisnis (FEB) \\ Universitas Pembangunan Nasional Veteran (UPNV) \\ Jakarta, Indonesia \\ *purwantowidodo@gmail.com
}

\begin{abstract}
This research aims to look at the behavior of capital structure determinants derived from corporate and macroeconomic characteristics and determinants of speed of adjustment based on company characteristics in the secondary and tertiary sectors. The research methodology uses dynamic panel data and is analyzed using the GMM (General Method of Moment) approach to obtain consistent and non-bias estimators. The results of the analysis showed that the company's characteristics variables: profitability, size, growth opportunity, tangibility, and business risk; Macroeconomic variables: economic growth, interest rates, and inflation have a significant effect on leverage. Based on the speed of adjustment (SOA) secondary and primary sectors, follow the Dynamic Trade-Off Theory. The effect of determinants of speed adjustment between secondary sectors is not the same as tertiary sectors. The research findings are profitability variable, the secondary sector consistently applies the Pecking Order Theory, whereas the tertiary sector is only in the short term. There is an effect of size (size effect) and growth opportunity (growth opportunity effect) both in the secondary sector and the tertiary sector.
\end{abstract}

Keywords-capital structure, determinant, the speed of adjustment

\section{INTRODUCTION}

Trade off Theory (TOT) or Balancing Theory, then called the Static Trade off Theory, was built to supplement the Irrelevant Theory Modigliani and Miller [1,2] then Miller [3] completed the conditions for individual taxation, bankruptcy costs [4], agency costs [5], asymmetrical information [6].

According Myers [7] companies that apply the TOT concept will set targeted leverage then gradually achieve it. Is Fischer [8] who introduced Dynamic Trade-Off Theory, it was shown that corporate leverage will move along with changes in determinants. Getzmann et al [9] companies will make adjustments all the time $[10,11]$.
Unfortunately, until now, there has been no agreement on the determinants of targeted leverage. Ozkan [10], Gaud et al [11], Mahakud and Mukherjee [12] used company characteristic variables, Cahyono and Chawla [13] added industry characteristic variables, Öztekin and Flannery [14], Haron and Ibrahim [15], macroeconomic variables; Ying et al. [16] human resource factor.

This study intends to analyze the behavior and determinants of targeted leverage and speed of adjustment in companies that are in the secondary and tertiary sectors listed on the Indonesia Stock Exchange. This research is expected to contribute to financial research regarding targeted leverage determinant behavior and speed of adjustment. To avoid the problem of endogeneity, the authors use the GMM (General Method of Moment) approach [17- 21].

\section{LITERATURE REVIEW}

\section{A. Dynamic Model}

The dynamic model is carried out to overcome the shortcomings of the static model in which its inability to capture the adjustment of actual leverage towards the targeted leverage is carried out [22]. Also, dynamic models can analyze targeted leverage and speed of adjustment in one model.

Hovakimian et al. [23] show that in ideal conditions, as referred to by Modigliani and Miller [1], the actual leverage will be the same as the targeted leverage, but in reality, there is a deviation so that the actual leverage will differ from the targeted leverage. In such conditions, the company will be faced with two choices, namely moving towards targeted leverage or staying in a distorted position. To return to the targeted leverage will require costs called adjustments costs [12]. 


\section{B. Factors Affecting Targeted Leverage and speed of adjustment}

1) Profitability: When a company has a high-profit rate implies that the company has large funds, to avoid information asymmetry [6], whixh will increase the speed of adjustment [23]. This research predicts a negative relationship with leverage and positive the speed of adjustment, proxy [24], is EBIT to Total Assets.

2) Size: Titman and Wessels [25] states that size is the default proxy variable, asymmetric information [12]. This study predicts that it will be positively related to leverage and, the speed of adjustment. Proxy [11], is Ln. from sales.

3) Growth opportunity: According to Gaud et al. [11] companies that are growing generally have revenue streams that tend to be more volatile, high risk and consequently have a high risk of bankruptcy; therefore, it is expected to be negatively related to leverage and positively related to speed of adjustment. Proxy [26] is a change in sales.

a) Tangibility: Companies that have high tangible assets will be easier to get debt so that it will reduce the cost of bankruptcy of the company [12]. This study predicts a positive relationship with leverage and speed of adjustment. Proxy [27] is Fixed Asset to Total Asset.

b) Business risk: De Haas and Peetes [24] state that high variability of returns has high company risk. Expected to be negatively related to leverage [28]. Proxy $[29,30]$ is changes in EBIT.

c) Economic growth: According to Hackbarth et al [31] the development of a country's macroeconomic conditions influences the movement of actual leverage towards targeted leverage. Predicted to be positively related to leverage. Proxy $[29,30]$ is annual GDP changes.

d) Inflation: Kim et al. [32] state that inflation tends to increase the amount of debt borne by companies, predicted to be positively related to leverage. Proxy with changes in the annual Consumer Price Index (CPI) [33].

e) Interest rates: Dincergok and Yalciner [34] which states that interest rates negatively affect leverage, because an increase in interest rates will make debt expensive. This study uses a proxy for the average interest rates of government banks and private banks.

\section{METHODS}

The unit of analysis is companies that are in the secondary and primary sectors listed on the Indonesia Stock Exchange, where the data is obtained from http://www.idx.co.id. The financial industry sector was then excluded because it had different characteristics. The companies taken are companies that have gone public before 2008 and still exist until 2015 and complete the data.

This study uses a proxy book value to measure leverage [10]. Proxy leverage (LEV) is measured by total debt to total assets. Total debt can reflect the true leverage ratio [13], then the analysis uses the Partial Adjustment Model (PAM). The PAM model was chosen because of adjustments towards optimal leverage. If $L E V_{i t}^{*}$ states the optimal leverage and $\delta_{i, t}$ the adjustment factor is written:

$$
L E V_{i, t}-L E V_{i, t-1}=\delta_{i, t}\left(L E V_{i, t}^{*}-L E V_{i, t-1}\right)
$$

While $L E V_{i t}^{*}=\beta^{\prime} x_{i t}+u_{i t}$ then the equation (1), become

$$
\begin{array}{cc}
L E V_{i, t}-L E V_{i, t-1}=\delta_{i, t}\left(\beta^{\prime} x_{i t}+u_{i t}-L E V_{i, t-1}\right) & \text { or } \\
L E V_{i, t}=\left(1-\delta_{i, t}\right) L E V_{i, t-1}+\delta_{i, t} \beta^{\prime} x_{i t}+\delta_{i, t} u_{i t}, & \text { so }
\end{array}
$$
simplified to be :

$$
L E V_{i, t}=\left(1-\delta_{i, t}\right) L E V_{i, t-1}+\delta_{i, t} \beta^{\prime} x_{i t}+\delta_{i, t} u_{i t} .
$$

Where $\mathrm{x}_{\mathrm{i}, \mathrm{t}}^{\prime}$ is a matrix of independent variables consisting of characteristics company and macroeconomic conditions, while $\delta_{i, t}$ is the speed of adjustment parameter. Equation 2 is dynamic panel data, if estimated based on OLS (Ordinary Least Square) will cause bias, because there is a correlation between $L E V_{i, t-1}$ with $\varepsilon_{i, t}[10,17,19,20,21]$. Therefore, the Generalized Method of Moment (GMM). GMM validation, carried out by: a). Wald test, b) Sargan test, c) Arrellano Bond test and d) unbiased. The GMM estimator is said to be unbiased if the coefficient value of the lag leverage obtained from the GMM process lies between the coefficients of the FE lag leverage and PLS/OLS [21].

\section{RESULTS AND DISCUSSION}

\section{A. Results}

For the secondary sector as many as 616 observations and tertiary sectors 560 observations. The test results can be seen in Table 1, Table 2 and table 3. The Wald test results, the Arrellano - Bond test for $\mathrm{m}_{1}$ (AR1) ase significant, $\mathrm{m}_{2}$ (AR2), the Sargan test and unbiased and consistency are consistent with expectations.

TABLE I. The DeterminANTS OF LEVERAge TARgETED AT SECONDARY SECTORS

\begin{tabular}{|c|l|l|l|l|l|l|l|}
\hline Variabel & \multicolumn{1}{|c|}{$(1)$} & \multicolumn{1}{|c|}{$(2)$} & \multicolumn{1}{|c|}{$(3)$} & \multicolumn{1}{|c|}{$(4)$} & \multicolumn{1}{|c|}{$(5)$} & \multicolumn{1}{c|}{$(6)$} & $(7)$ \\
\hline Lag LEV & $0.658^{* * *}$ & $0.588^{* * *}$ & $0.730^{* * *}$ & $0.729^{* * *}$ & $0.642^{* * *}$ & $0.650^{* * *}$ & $0.612^{* * *}$ \\
\hline SOA & $34.13 \%$ & $41.15 \%$ & $26.96 \%$ & $27.09 \%$ & $35.76 \%$ & $34.94 \%$ & $38.71 \%$ \\
\hline PROF & $-0.386^{* * *}$ & $-0.332^{* * *}$ & $-0.171^{* * *}$ & $-0.205^{* * *}$ & $-0.576^{* * *}$ & $-0.573^{* * *}$ & $-0.407 * * *$ \\
\hline Lag PROF & & $-0.198^{* * *}$ & & & & & \\
\hline SIZE & $0.779 * * *$ & $1.506^{* * *}$ & & & $0.359 * * *$ & $0.863^{* * *}$ & $1.772^{* * *}$ \\
\hline
\end{tabular}


Table 1. Cont.

\begin{tabular}{|c|c|c|c|c|c|c|c|}
\hline BSIZE & & & $0.314 * * *$ & & & & \\
\hline SSIZE & & & & $0.236 * * *$ & & & \\
\hline TANG & $0.259 * * *$ & $0.191 * * *$ & $0.285 * * *$ & $0.316^{* * * *}$ & $0.368 * * *$ & $0.308 * * *$ & $0.248 * * *$ \\
\hline GROWTH & $-0.090 * * *$ & -0.279 *** & $-0.211^{* * * *}$ & $-0.221 * * *$ & & & $-0.244 * * *$ \\
\hline SGROWTH & & & & & -0.247 *** & & \\
\hline BGROWTH & & & & & & -0.052 & \\
\hline RISK & $-0.000 * * *$ & $-0.000 * * *$ & $-0.000 * * *$ & -0.000 **** & $-0.000^{* * * *}$ & -0.000 **** & $-0.000 * * *$ \\
\hline$D B R B$ & & & & & & & $1.404 * * *$ \\
\hline INFLASI & & & & & & & $0.148 * * * *$ \\
\hline$B U N G A$ & & & & & & & $-1.295 * * *$ \\
\hline Wald chi 2 & $68455^{* * * *}$ & $26016^{\text {**** }}$ & $11305 * * *$ & $13083^{* * * *}$ & $68777 * * *$ & 49119 *** & 56877 **** \\
\hline$m 1$ (AR1) & $-1.987 * *$ & -2.710 *** & $-2.220 * *$ & $-2.377 * *$ & $-2.321 * *$ & $-2.039 * *$ & $-2.528 * *$ \\
\hline$m 2$ (AR2) & 0.63579 & 0.74729 & 0.62161 & 0.68616 & 0.76146 & 0.66311 & 0.85069 \\
\hline Sargan & 55.29265 & 43.4664 & 38.21869 & 43.45622 & 67.09055 & 66.06204 & 58.29015 \\
\hline Lag LEV FE & $0.424 * * *$ & $0.349 * * *$ & $0.426 * * *$ & $0.426 * * *$ & $0.420 * * *$ & $0.426 * * *$ & $0.417 * * *$ \\
\hline Lag LEV OLS & 0.893 **** & 0.908 *** & $0.913 * * *$ & $0.910 * * *$ & 0.880 *** & $0.902 * * *$ & $0.893 * * *$ \\
\hline
\end{tabular}

TABLE II. The DeterminANTS OF LeVERAge TARgeted AT Tertiary SECTORS

\begin{tabular}{|c|c|c|c|c|c|c|c|}
\hline Variabel & (1) & (2) & (3) & (4) & (5) & (6) & (7) \\
\hline Lag LEV & $0.466 * * *$ & $0.488 * * *$ & $0.626^{* * * *}$ & $0.687 * * *$ & $0.449 * * *$ & $0.457 * * *$ & $0.449 * * *$ \\
\hline$S O A$ & $53.36 \%$ & $51.10 \%$ & $37.32 \%$ & $31.27 \%$ & $55.09 \%$ & $54.27 \%$ & $55.04 \%$ \\
\hline PROF & $-0.182 * * *$ & $-0.196 * * *$ & $-0.115 * * *$ & $-0.071 * *$ & $-0.169 * * *$ & $-0.168^{* * *}$ & $-0.257 * * *$ \\
\hline Lag PROF & & $0.046^{* * *}$ & & & & & \\
\hline SIZE & $2.045 * * *$ & $1.951 * * *$ & & & $1.924 * * *$ & $2.120 * * *$ & $2.567 * * *$ \\
\hline BSIZE & & & $0.669 * * *$ & & & & \\
\hline SSIZE & & & & 0.134 *** & & & \\
\hline TANG & $0.049 * * *$ & $0.055^{* * *}$ & $0.134 * * *$ & 0.139 *** & $0.132 * * *$ & $0.129 * * *$ & $0.091 * * *$ \\
\hline GROWTH & $-0.073 * * *$ & $-0.073 * * *$ & $-0.074 * * *$ & $-0.074 * * *$ & & & $-0.050 * * *$ \\
\hline SGROWTH & & & & & $-0.022 * * *$ & & \\
\hline BGROWTH & & & & & & $-0.071 * * *$ & \\
\hline RISK & $-0.000 * * * *$ & $-0.000 * * *$ & $-0.000 * * *$ & $-0.000 * * *$ & $-0.000 * * *$ & $-0.000^{* * * *}$ & $-0.000 * * *$ \\
\hline$D B R B$ & & & & & & & $0.841 * * *$ \\
\hline INFLASI & & & & & & & $-0.022 * *$ \\
\hline$B U N G A$ & & & & & & & $-0.892 * * *$ \\
\hline Wald chi 2 & 1540000 & 1650000 & 138158 & 149397 & 225191 & 96399 & 16311 \\
\hline$m 1$ (ARI) & $-2.127 * *$ & $-2.143 * *$ & $-2.163 * *$ & $-2.176^{* *}$ & $-2.034 * *$ & $-2.105 * *$ & $-2.021 * *$ \\
\hline$m 2$ (AR2) & -1.2626 & -1.2323 & -1.2124 & -1.3678 & -1.2564 & -1.2788 & -1.3898 \\
\hline Sargan & 72.38577 & 70.89032 & 63.69691 & 65.21608 & 59.94028 & 58.17493 & 69.6564 \\
\hline Lag LEV FE & $0.289 * * *$ & $0.280 * * *$ & $0.293 * * *$ & $0.295 * * *$ & $0.292 * * *$ & $0.287 * * *$ & $0.274 * * *$ \\
\hline Lag LEV OLS & $0.807 * * *$ & $0.823 * * *$ & $0.915 * * *$ & $0.948 * * *$ & $0.803 * * *$ & $0.807 * * *$ & $0.804 * * *$ \\
\hline
\end{tabular}

Note: The BSIZE variable is SIZE variable, which is smaller than the median variable SIZE $=0$. The SSIZE Variable SSIZE is SIZE variable, which is more than the median SIZE variable $=0$. The SGROWTH variable is GROWTH variable which more than median GROWTH variable $=0$. The BGROWTH variable is GROWTH variable which is smaller than the median GROWTH variable $=0$. *** signifikan pada level $\mathrm{p}<0.01, * *$ signifikan pada level $\mathrm{p}<0.05$ dan $*$ signifikan pada level $\mathrm{p}<0.1$

TABLE III. THE DETERMINANTS OF LEVERAGE TARGETED AT SECONDARY AND TERTIARY SECTOR

\begin{tabular}{|c|l|l|}
\hline Variabel & \multicolumn{1}{|c|}{ Sekunder } & \multicolumn{1}{|c|}{ Tertier } \\
\hline Lag LEV & $0.358^{* * *}$ & $0.1813^{* * *}$ \\
\hline Lag LEV*PROF & $-0.0082^{* * *}$ & $-0.00274^{* * *}$ \\
\hline Lag $L E V^{*}$ SIZE & -0.0133 & $0.0290^{* * *}$ \\
\hline Lag $L E V^{*} T A N G$ & $0.0026^{* * *}$ & -0.0002121 \\
\hline Lag LEV GROWTH & $-0.0014^{* * *}$ & $-0.00186^{* * *}$ \\
\hline Wald chi2 & 7776.63 & 13499.48 \\
\hline m1 (AR1) & $-1.8711^{*}$ & $-2.0896^{* *}$ \\
\hline m2 (AR2) & 0.69027 & -1.4697 \\
\hline Sargan & 25.85914 & 44.23285 \\
\hline Lag LEV FE & -0.2867727 & $-0.3900^{* *}$ \\
\hline Lag LEV OLS & $0.74888^{* * *}$ & $0.84806^{* *}$ \\
\hline
\end{tabular}

The results of the analysis of the Table 1 and Table 2 show that the lag leverage coefficient (Lag LEV) is positive, significance and smaller than 1 [25]. The study proves that the dynamic model of capital structure on average applies to secondary and tertiary sectors. These results are the same as [15].

Table 1 and table 2 show that coefficient of profitability variable (PROF) is negative and significant. Profitability according to Baskin [36], Bontempi [37] is determining variable Trade Off Theory or Pecking Order Theory (POT). These results are the same as Gaud et al [11]. In accordance with Gaud et al. [11], the authors add Lag Profitability to test consistency of POT. The results in Tabel 1 show that coefficient Lag PROF negative and significance, showing that POT is consistent in the secondary sector, similar to [16], while in Table 2 positive and significance, according to research Gaud et al [11]. This results show that behavior of POT in the tertiary sector only applies to short run. Gaud et al 
[11] stated that banks consider the profitability of the company before.

Table 1 and Table 2 show that the coefficient of the SIZE variable is positive and significant. In accordance with TOT the large companies have more diversified products so that creditors consider to have a low risk [11]. The author than add BSIZE which had a greater value yhan the median, and SSIZE smaller. The result is that the coefficient of BSIZE (0.31412) is greater than that of SSIZE (0.23688), is meaning that a company that has large SIZE will have a stronger effect on leverage.

Table 1 and Table 2 show that the coefficient of the Tangibility (TANG) variables is positive and significant. The companies that have high fixed assets can be borrow at lower interest rates [5]. Frank and Goyal [38] as a determinant variable in the company's capital structure. The results of the study are in line with research by Haron and Ibrahim [15], Haron et al. [29], Haron et al. [30].

Table 1 and Table 2 show that the coefficient of the Growth Opportunity (GROWTH) variables is negative and significance. The companies that have high growth opportunities have high risks. In The results of the study are in line with research by Ying et al. [16], Haron et al. [29], Haron et al. [30]. Then the SGROWTH variable is added, which is smaller than the median GROWTH variables and $v$ BGROWTH, which is the larger the median GROWTH variable. The results of this study are: the coefficient of SGROWTH variable $(-0.24700)$ less than BGROWTH variables $(-0.05220)$, meaning that companies that have small GROWTH will have strong effect on leverage.

Table 1 and Table 2 show that the coefficient of the Business Risk (RISK) variable is negative and significant. The companies that have high Business Risk have high income volatility so that they have a high bankruptcy risk due to high uncertainty. In accordance with Maghyereh [18], Nivorozhkin [28], Haron et al. [29], and Haron et al [30].

Table 1 and Table 2 show that the coefficient of the Economic Growth (GPDRB) variable is positive and significant. When economic conditions improve, companies tend to increase the amount of debt. In accordance with Memon an Ghazali [39].

Table 1 and Table 2, show that the coefficient of the Inflation (INFLASI) variable is positive and significant. The high of the Inflation causes the stock price to be undervalued, so managers tend to reduce funding using shares and increase debt. In accordance with Memon an Ghazali [39].

Table 1 and Table 2 show that the coefficient interest rate variable (BUNGA) is negative and significant. When the economic conditions improve, interest rates will fall so that the cost of capital will be low, according to the POT, the company will increase the amount of debt. These results are in accordance Antoniou et al [40].
Table 1 show that the speed of adjustment (SOA) the secondary sector range from $26.96 \%$ to $38.71 \%$, while tertiary sector in Table 2, showed that $31.27 \%$ to $55.09 \%$. The magnitude of speed of adjustment between $30 \%$ to $40 \%$ show that the secondary sector and tertiary sector are accordance with Dynamic Trade Off Theory [21].

SOA determinant variables, the author use Mahakud and Mukherjee [12] method that is the independent variable interaction between Lag Leverage with independen variables. This study uses independent variables: Profitability, Size, Tangibility and Growth Opportunity. The interpretation is: if the coefficient of the Lag leverage interaction with independen variables is positive, it indicates that the variable will reduce leverage or have negative effect, and vice versa.

Table 3 show that the interaction between Lag Leverage variable with PROF variable, sign is negative and significant both for secondary and tertiary sectors, meaning that the greater the profitability of the company, the SOA will be higher, because the profitability will reduce internal constraints [41], increasing free cash flow [42]. These results are accordance with the research of the Mahakud and Mukherjee [12], Haron et al [29], Haron et al. [30].

Table 3 show that the interaction between Lag Leverage variable with SIZE variable, sign is negative but not significance for secondary sector, positive and significance for tertiary sector, not accordance with the hypothesis proposed. This result is accordance with the research of Elsas and Florysiak [43].

Table 3 show that the interaction Lag Leverage variable with TANG variable, sign is positive for secondary sector and negative but not significant for tertiary sector, this meaning the greater Tangibility of a company, the SOA will be lower, because it tends to be slower. These results are in accordance with the research of [12].

\section{CONCLUSIONS}

This research is able to prove that the determinants of the company's capital structure which are the characteristicthe of the company and the macro economy condition have significant effect and are in accordance with predicted in both secondary and tertiary sectors. Based on profitability variable, sector secondary sector tends to consistently apply Pecking Order Theory, whereas the tertiary sector, only applies for the short term. In addition, the size effect and growth opportunity effect.

Based on the speed of adjustment, on an average it follows Dynamic Trade Off Theory, so as to increasing the value of the firm, it can be done by increasing the level of the company's debt to the limit determined by the Peraturan Menteri Keuangan (PMK) number 169/PMP.010/2015. The results of this study, incate that there are differences in the influence of the determinants of the corporate company characteristics on the speed of adjustment for the secondary and the tertiary sector. 


\section{REFERENCES}

[1] F. Modigliani and M.H. Miller, "The cost of capital, corporation finance and the theory of investment," Am. Econ. Rev., vol. 48, no. 3, pp. 261$297,1958$.

[2] F. Modigliani and M.H. Miller, "Corporate income taxes and the cost of capital: a correction," Am. Econ. Rev., vol. 53, no. 3, pp. 433-443, 1963

[3] M.H. Miller, "Debt and taxes," J. Finance, vol. 32, no. 2, pp. 261-275, 1977.

[4] J.E. Stiglitz, "Taxation, corporate financial policy, and the cost of capital,"J. Public Econ., vol. 2, no. 1, pp. 1-34, 1973.

[5] M.C. Jensen and W.H. Meckling, "Theory of the firm: Managerial behavior, agency costs and ownership structure," J. financ. econ., vol. 3, no. 4, pp. 305-360, 1976.

[6] S.C. Myers and N.S. Majluf, "Corporate financing and investment decisions when firms have informationthat investors do not have," National Bureau of Economic Research, 1984.

[7] S.C. Myers, "Capital structure puzzle," National Bureau of Economic Research, 1984

[8] E.O. Fischer, R. Heinkel, and J. Zechner, "Dynamic capital structure choice: Theory and tests,” J. Finance, vol. 44, no. 1, pp. 19-40, 1989.

[9] A. Getzmann, S. Lang, and K. Spremann, "Target capital structure determinants and speed of adjustment analysis to address the KeynesHayek debate," J. Rev. Glob. Econ., vol. 4, pp. 225-241, 2015.

[10] A. Ozkan, "Determinants of capital structure and adjustment to long run target: evidence from UK company panel data," J. Bus. Financ. Account., vol. 28, no. 1-2, pp. 175-198, 2001.

[11] P. Gaud, E. Jani, M. Hoesli, and A. Bender, "The capital structure of Swiss companies: an empirical analysis using dynamic panel data," Eur. Financ. Manag., vol. 11, no. 1, pp. 51-69, 2005.

[12] J. Mahakud and S. Mukherjee, "Determinants of adjustment speed to target capital structure: Evidence from Indian manufacturing firms," in International Conference on Economics and Finance Research, 2011, vol. 4 , no. 1 .

[13] S.B. Cahyono and A.S. Chawla, "Dynamic capital structure in Indonesian case: do industry-specific variables affect adjustment speeds?," Invest. Manag. Financ. Innov., vol. 16, no. 2, p. 218, 2019.

[14] Ö. Öztekin and M.J. Flannery, "Institutional determinants of capital structure adjustment speeds," J. financ. econ., vol. 103, no. 1, pp. 88 112, 2012.

[15] R. Haron and K. Ibrahim, "Target capital structure and speed of adjustment: Panel data evidence on Malaysia Shariah compliant securities,” Int. J. Econ. Manag. Account., vol. 20, no. 2, 2012.

[16] Y. Ying, M. Albaity, and C.H. Bin Hassan, "How dynamic capital structure works in China," Int. J. Res. Bus. Technol., vol. 7, no. 2, pp. 891-901, 2015.

[17] M. Verbeek, A guide to modern econometrics. John Wiley \& Sons, 2008

[18] A. Maghyereh, "Dynamic capital structure: Evidence from the small developing country of Jordan,” Int. J. Econ. Manag. Account., vol. 13, no. 1,2005

[19] D. Roodman, "How to do xtabond2: An introduction to difference and system GMM in Stata," stata J., vol. 9, no. 1, pp. 86-136, 2009.

[20] M. Arellano and S. Bond, "Some tests of specification for panel data: Monte Carlo evidence and an application to employment equations," Rev. Econ. Stud., vol. 58, no. 2, pp. 277-297, 1991.

[21] Z. Xu, "Do firms adjust toward a target leverage level?," Bank of Canada, 2007.
[22] A. Heshmati, "The dynamics of capital structure: Evidence from Swedish micro and small firms," Res. Bank. Financ., vol. 2, no. 1, pp. 199-241, 2001.

[23] A. Hovakimian, T. Opler, and S. Titman, "The debt-equity choice," J Financ. Quant. Anal., pp. 1-24, 2001.

[24] R. De Haas and M. Peeters, "The dynamic adjustment towards target capital structures of firms in transition economies," Econ. Transit., vol. 14, no. 1, pp. 133-169, 2006.

[25] S. Titman and R. Wessels, "The determinants of capital structure choice," J. Finance, vol. 43, no. 1, pp. 1-19, 1988.

[26] K. Mazur, "The determinants of capital structure choice: evidence from Polish companies," Int. Adv. Econ. Res., vol. 13, no. 4, pp. 495-514 2007.

[27] S. Banerjee, A. Heshmati, and C. Wihlborg, The dynamics of capital structure. Citeseer, 1999.

[28] E. Nivorozhkin, "The dynamics of capital structure in transition economies," Econ. Plan., vol. 37, no. 1, pp. 25-45, 2004

[29] R. Haron, K. Ibrahim, F.M. Nor, and I. Ibrahim, "Factors affecting speed of adjustment to target leverage: Malaysia evidence," Glob. Bus. Rev., vol. 14, no. 2, pp. 243-262, 2013.

[30] R. Haron, K. Ibrahim, F.M. Nor, and I. Ibrahim, "Dynamic adjustment towards target capital structure: Thailand Evidence," J. Pengur. (UKM J. Manag., vol. 39, 2013.

[31] D. Hackbarth, J. Miao, and E. Morellec, "Capital structure, credit risk, and macroeconomic conditions," J. financ. econ., vol. 82, no. 3, pp. 519550, 2006.

[32] S.-J. Kim, B.M. Lucey, and E. Wu, "Dynamics of bond marke integration between established and accession European Union countries," J. Int. Financ. Mark. Institutions Money, vol. 16, no. 1, pp. 41-56, 2006.

[33] B. Budiono and N. Septiani, "Pengaruh Inflasi, Suku Bunga Sbi, Kurs Us Dollar Terhadap Rupiah, Pajak, Solvabilitas, Dan Profitabilitas Terhadap Struktur Modal Pada Perusahaan Lq-45 Yang Terdaftar Di Bursa Efek Indonesia Periode 2010-2015," BISMA (Bisnis dan Manajemen), vol. 9, no. 2, pp. 119-134, 2018.

[34] B. Dincergok and K. Yalciner, "Capital structure decisions of manufacturing firms' in developing countries," Middle East. Financ. Econ., vol. 12, no. 7, pp. 86-100, 2011.

[35] W. Drobetz, P. Pensa, and G. Wanzenried, "Firm characteristics, economic conditions and capital structure adjustments," Econ. Cond. Cap. Struct. Adjust. (January 2007), 2007.

[36] J. Baskin, "An empirical investigation of the pecking order hypothesis," Financ. Manag., pp. 26-35, 1989.

[37] M.E. Bontempi, "The dynamic specification of the modified pecking order theory: its relevance to Italy," Empir. Econ., vol. 27, no. 1, pp. 1 22, 2002.

[38] M.Z. Frank and V.K. Goyal, "Capital structure decisions: which factors are reliably important?," Financ. Manag., vol. 38, no. 1, pp. 1-37, 2009.

[39] P.A. Memon and Z. Ghazali, "Firm and macroeconomic determinants of debt: Pakistan evidence," Procedia-Social Behav. Sci., vol. 172, pp. 200-207, 2015

[40] A. Antoniou, Y. Guney, and K. Paudyal, "The determinants of capital structure: capital market-oriented versus bank-oriented institutions," J. Financ. Quant. Anal., pp. 59-92, 2008

[41] S. Myers and R.G. Rajan, "Liquidity and the rise of financial intermediation," in Federal Reserve Bank of Chicago Proceedings, 1995, no. 468 .

[42] M. Flannery and K.W. Hankins, "Estimating dynamic panels," Working Paper, 2007.

R. Elsas and D. Florysiak, "Heterogeneity in the speed of adjustment toward target leverage,” Int. Rev. Financ., vol. 11, no. 2, pp. 181-211, 2011 